\begin{tabular}{|c|c|}
\hline 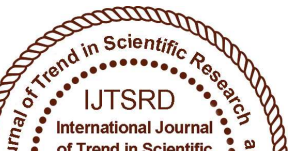 & $\begin{array}{l}\text { International Journal of Trend in Scientific } \\
\text { Research and Development (IJTSRD) }\end{array}$ \\
\hline 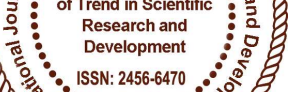 & International Open Access Journal \\
\hline 000 & ISSN No: 2456 - 6470 | www.ijtsrd.com | Volume - 2 | Issue - 3 \\
\hline
\end{tabular}

\title{
Experimental Investigational Study on the Physical Properties of a new Concrete Mixture Prepared with Recycled Aggregate
}

\author{
Bhupendra Kirar \\ PG Student, Civil Engineering Department, \\ Radharaman Engineering College \\ (REC), Bhopal, Madhya Pradesh, India
}

\author{
K G Kirar \\ Assistant Professor \& Head of Department, Civil \\ Engineering Department, Radharaman Engineering \\ College (REC), Bhopal, Madhya Pradesh, India
}

\section{ABSTRACT}

Recycled aggregates (RA) are consists of crushed concrete, inorganic particles developed from the materials that have been already used in the structural constructions and demolition (C and D) debris. The aim of this thesis is to determine the strength characteristics of the recycled aggregates for application in the high strength structural concrete, which will provide a improved understanding on the properties of concrete with recycled aggregates, as an unconventional material to coarse aggregate i.e. natural aggregate in structural concrete. The aim of this thesis is to determine and compare the strength of concrete by using different percentage of the recycled aggregates.

Recycled aggregate is moreover the type of artificial aggregate which is obtained from the Construction and demolition (C \& D) wastes. The Constructions and demolitions are processes that go one after the other. The demolished building aggregate in India generally goes to waste in land filling operation. Recycling of these waste materials from building demolition can provide a better solution to this problem.

The research investigation was carried out using the sieve analysis test, Specific gravity test, Water absorption test, Aggregate Impact Value (AIV) test, Crushing value test, Workability test (Slump cone test) and compressive strength test. There were total of five batches of concrete mixes, consisting of every $25 \%$ increment of recycled aggregate replacement, from $0 \%$ to $100 \%$ i.e. $0 \%, 25 \%, 50 \%, 75 \%$ and $100 \%$.

\section{INTRODUCTION}

In present scenario there is a remarkable reduction in high-quality aggregate available for the construction use. Universally aggregate utilization is estimated to be 10 to 12 billion tonnes per year out of this quantity; approximately 8 billion tonnes of aggregate (sand, gravel, and crushed rock) is being used in Portland cement concrete (PCC) each year (Naik 2005, Mehta 2001). In the central Canada, 14 tonnes of aggregate are utilized per person every year. However, for every 3 tonnes of aggregate that i.e. produced merely 1 tonne is replaced by opening new aggregate sources or through the recycling process (Mac Naughton I, 2004). Ontario is presently using aggregate faster than it's being made available resulting in an aggregate shortage.

The present situation of aggregate resources in Ontario is not completely known since the most recent detailed study was done in the year 1992 by the Ministry of Natural Resources (MNR) in "State of the Resource Report” (Miller 2005).

\section{1- Introduction of Recycled Aggregate}

Construction and demolition (C \& D) are the processes that go one after the other. The demolished building material and aggregate in India generally used as a filler material i.e. used in filling of foundation. After few years construction and 
demolition waste will be more than half of the total National waste in most countries of the world so recycling of these concrete waste materials can offer an effective solution to this problem of construction and demolition waste.

\section{2- Natural Aggregate (NA)}

Naturally occurring aggregates are a mixture of the rocks and minerals. A mineral is a naturally occurring solid matter with an organized internal structure and a chemical composition that ranges within restrictions. Rocks, which are classified as igneous rocks, sedimentary rocks and metamorphic rocks depending upon their origin, are generally composed of a number of minerals. Say for example granite contains feldspar, mica, quartz and some other minerals and most lime stones consist of the calcite and minor amounts of quartz, clay and feldspar.

\section{3- Recycled Concrete Aggregate (RCA)}

Recycled concrete aggregate (RCA) is generally produced by two stage crushing of the demolished concrete, screening and then removal of pollutants such as reinforcement, wood, plastic and gypsum. The concrete which is made with such recycled aggregate is called as recycled aggregate concrete (RAC).

Table-1 Different types of Recycled Aggregate

\begin{tabular}{|c|c|c|}
\hline Type of Aggregates & Description & Application \\
\hline $\begin{array}{l}\text { Recycled Concrete } \\
\text { Aggregate (RCA) }\end{array}$ & $\begin{array}{l}\text { Crushed sound and clean waste } \\
\text { Concrete of at least } 95 \% \text { by weight of } \\
\text { concrete with typical total } \\
\text { contamination lower than } 1 \% \text { of the } \\
\text { bulk mass. } \\
\text { Class 1A RCA is a well graded RCA } \\
\text { with no more than } 0.5 \% \text { brick content. }\end{array}$ & $\begin{array}{l}\text { Partial replacement (30\%) for natural } \\
\text { aggregate in concrete for sidewalks, } \\
\text { curbs and gutters. Also for structural } \\
\text { concrete (with mix adjustment) and } \\
\text { inferior permeability and Shrinkage } \\
\text { properties. }\end{array}$ \\
\hline $\begin{array}{l}\text { Recycled Concrete and } \\
\text { Masonry } \quad \text { Aggregate } \\
\text { (RCMA) }\end{array}$ & $\begin{array}{l}\text { Graded aggregate produced from } \\
\text { sorted and clean waste concrete and } \\
\text { masonry. } \\
\text { Class 1B RCA is a class } 1 \mathrm{~A} \text { RCA } \\
\text { blended with no more than } 30 \% \text { crush } \\
\text { brick. }\end{array}$ & Road base course and sub base material. \\
\hline $\begin{array}{l}\text { Reclaimed } \\
\text { (RA) }\end{array}$ & $\begin{array}{l}\text { Coarse aggregates reclaimed from } \\
\text { returned concrete by separating the } \\
\text { aggregates from the water-cement } \\
\text { slurry. }\end{array}$ & $\begin{array}{l}\text { Up to } 32-\mathrm{MPa} \text { concrete with } 100 \% \\
\text { reclaimed aggregates, and as partial } \\
\text { replacement of natural aggregate in } \\
\text { grades up to } 80 \mathrm{MPa} \text {. }\end{array}$ \\
\hline $\begin{array}{l}\text { Reclaimed Asphalt } \\
\text { Pavement (RAP) }\end{array}$ & Old asphalt concrete & $\begin{array}{l}\text { New asphaltic } \text { concrete } \\
\text { pavement.RAP/RCA blends for RCC in } \\
\text { flexible pavement and sub-grade } \\
\text { material. }\end{array}$ \\
\hline $\begin{array}{l}\text { Reclaimed Asphalt } \\
\text { Aggregate (RAA) }\end{array}$ & $\begin{array}{l}\text { Reclaimed coarse aggregate and } \\
\text { recycled asphalt granules from waste } \\
\text { asphalt concrete. }\end{array}$ & $\begin{array}{l}\text { Concrete with penalties in } \operatorname{mix} \\
\text { adjustment. }\end{array}$ \\
\hline
\end{tabular}

The implementations of the Recycled concrete aggregate (RCA) in the construction areas are wide and they had been used from long time ago.

The wide-ranging research on Recycled concrete aggregate (RCA) as started from year 1945 in various part of the world after Second World War, but in a uneven or uncontinous manner. First attempt has been done by Nixon in the year 1977 who complied all the work on RA carried out between the year 1945-1977 and prepared a state of the art report on it for RILEM technical committee 37-DRC.

CRISO and Wilmot (2004) stated that Recycled concrete aggregate (RCA) have been used in the road construction industry for the last 100 years. They also stated that the use of Recycled concrete aggregate (RCA) for the construction and rehabilitation of local 
government roads has a great improve in the last five years.

\section{Applications of Recycled Concrete Aggregate (RCA)}

Conventionally, the application of Recycled concrete aggregate (RCA) is used as landfill. At the present time, the applications of Recycled concrete aggregate (RCA) in construction areas are huge. The uses are different from country to country. Concrete waste was transported to landfills for disposal but recycling has a number of advantages that have made it a more attractive option in this period of greater environmental awareness more environmental laws and the desire to keep construction costs as low as possible.

Concrete aggregate collected from the demolition sites is put through a crushing machine, frequently along with asphalt, bricks, dirt, and rocks. Crushing facilities accept only uncontaminated cement concrete, which must be free of polythene, wood waste, paper waste and other such materials. Metals such as rebar are accepted, since they can be removed with magnets and other sorting devices and melted down for recycling somewhere else. The outstanding aggregate chunks are arranged by their sizes. Smaller pieces of cement concrete are used as gravel for new construction projects. Sub-base gravel is laid down as the bottom most layers in a road, with fresh concrete mix or asphalt poured over it. Crushed recycled concrete can also be used as the dry aggregate for brand new concrete mixture if it is free of impurities.

\section{A) Concrete Curb and Gutter Mix}

Recycled concrete aggregate (RCA) have been used as concrete curb and gutter mix in Australia. According to Building Innovation \& Construction Technology (BICT) (1999), states that the $10 \mathrm{~mm}$ size RCA and blended recycled sand are used for concrete curb and gutter mix in the Lenthall Street project in Sydney (Australia). Successful application of Recycled concrete aggregate (RCA) in construction projects has been reported in some European and American countries, as reviewed by Desmyster and Vyncke. At the same time as this type of material has been used in a large amount in non structural concretes or used as road bases, its use in the structural concrete is limited. Only in some cases have been reported on the use of Recycled concrete aggregate (RCA) in structural concrete and the amount of Recycled concrete aggregate (RCA) used has generally been limited to a low level of replacement of the total weight of coarse aggregate.

\section{B) Granular Base Course Materials}

According to the research carried by Market Development Study for Recycled Aggregate Products in the year 2001, Recycled concrete aggregate (RCA) are used as granular base course in the road construction. It also stated that Recycled concrete aggregate (RCA) had proved that better than natural aggregate (NA) when used as granular base course in roads construction. They too found that when the road is lying on the wet sub grade areas, Recycled concrete aggregate (RCA) will stabilize the base and provide an improved working surface for pavement structure construction.

While at present typically recycled into road sub base, the amount of demolished cement concrete is expected to increase rapidly and exceed the demand for road sub base in the near future. To encourage the recycling of concrete, a technology to produce highquality Recycled concrete aggregate (RCA) has been developed. In sequence to explore a future concrete recycling system, initially, a detailed model considering indices of economic activity is recognized to forecast the amount of demolished concrete in the coming future.

\section{C) Embankment Fill Materials}

Market Development Study for Recycled Aggregate Products (2001) stated that Recycled concrete aggregate (RCA) can be used in the embankment filling. The reason for being able to use in the embankment fill is same as it is used in the granular base course construction. The embankment site is on the wet sub grade areas. Recycled concrete aggregate (RCA) can stabilize the base and provide an improved working surface for the remaining construction works.

\section{D) Paving Blocks Construction}

Recycled concrete aggregate (RCA) have been used as paving blocks in Hong Kong, (2004). According to Hong Kong Housing Department (HKHD) recycled concrete aggregate (RCA) are used as typical paving blocks. A trial project had been started to test the long term performance of the paving blocks made with recycled concrete aggregate (RCA) in the year 2002 . Internationally, the RILEM specification is the most commonly accepted standard for recycled concrete 
aggregate (RCA). But in Hong Kong, (2004), due to our limited understanding in using recycled concrete aggregate (RCA) and Hong Kong's different nature of building construction, a more careful approach has been adopted. After detailed laboratory investigations and plant trials, the government has formulated two sets of specifications governing the use of recycled concrete aggregate (RCA) for cement concrete production.

\section{E) Backfill Materials}

Recycled concrete aggregate (RCA) can be used as backfill materials. Mehus and Lillestol, (2000) recognized so as to Norwegian Building Research Institute (NBRI) declared that recycled concrete aggregate (RCA) can be used as a backfill materials in the pipe region alongside trenches or pits after having testing in the laboratory.

\section{F) Building Blocks Construction}

Recycled concrete aggregate (RCA) used as a building blocks. Mehus and Lillestol, (2000) stated that we used recycled concrete aggregate (RCA) to produce the masonry sound insulation blocks. The masonry sound insulation blocks that produced had got together all the requirements during the laboratory testing period. This study targeted to develop a technique for producing the cement concrete bricks and paving blocks using recycled concrete aggregate (RCA) obtained from the construction and demolition (C \& D) waste. Laboratory experiments were carried out to observe the opportunity of using recycled concrete aggregate (RCA) from the different sources in The Hong Kong, as the replacement of both coarse aggregate and fine natural aggregates in the molded bricks and molded blocks. A chain of tests were conducted to find out the various properties of the bricks and blocks prepared with and with-out recycled concrete aggregate (RCA). The test results showed that the replacement of coarse and fine natural aggregates by recycled concrete aggregate (RCA) at the levels of $25 \%$ and $50 \%$ had modest effect on the compressive strength of the brick and block specimens, but higher levels of replacement reduced the compressive strength of the prepared specimen. However, the transverse strength of the specimens increased as the percentage of replacement increased. Utilizing the recycled aggregates as the partial replacement of natural aggregates (NA) at the level of up to $100 \%$, concrete paving blocks with a 28 -day compressive strength of not less than $49 \mathrm{MPa}$ can be produced without the incorporation of fly ash, while paving blocks for footway uses with a lower compressive strength of $30 \mathrm{MPa}$ and masonry bricks can be produced with the incorporation of fly ashes.

\section{LITERATURE REVIEW}

Sustainability is explained by the World Commission on Environment and Development as "Fulfilling the requirements of the present time without compromising the facility of the future generations to meet their own requirements" (Naik 2005). One researcher in his paper describes the achieving sustainability as the greatest challenge facing the concrete industry in the 21 st century (Mehta 2001). He claims that the concrete industry has a temporary view point on the consumption of natural resources (Mehta 2001) and so as to "in a finite world the model of limitless growth, unrestricted use of natural resources and uncontrolled pollution of the environment is a formula for planetary selfdestruction." The Factor of Ten Club states that "Within one generation, countries can attain a multiple time increase in the efficiency with which they usel energy, natural resources and other materials" (Mehta 2001).

As the environmental protection is becoming a most important public concern, the utilization of sustainable materials in the field of construction is gaining recognition all around the world. The utilization of the construction wastes for the making of new sustainable concrete is, on the other hand, not a new research area. From olden times it was established that Romans regularly used C \& D waste or debris for the road construction work (Tabsh and Abdelfatah 2009). Recycled Aggregate Concrete has been reported to provide environmental benefits through both its production and utilization, therefore, providing a greener as well as more sustainable solution of this problem. By using the concrete waste as aggregate for producing a new concrete, natural resources (e.g. gravel pits, rock quarries) can be sealed, which can abolish other associated manufacturing processes, e.g. excavation, blasting, transportation, crushing etc. When an old structure is demolished, the demolition wastes furthermore must be sent to the landfills. These processes involve the cost of material handling, dumping and also transportation cost. The use of $\mathrm{C} \& \mathrm{D}$ waste will substantially decrease the landfill use. 


\section{1- Recycled Concrete Aggregate (RCA)}

The applications of recycled concrete aggregate (RCA) in the construction area are very broad. There are so many testing based on the recycled concrete aggregate (RCA) have been carried out all around the world. Some of the literature reviews on recycled concrete aggregate (RCA) are shown as below.

The main object of testing the recycled aggregate is to determine the result of the strength characteristic and investigation whether recycled aggregate is suitable to apply in the construction area. According to Rammamurthy and Gumaster, (1998), the compressive strength of recycled aggregate concrete was comparatively lower and variation was depended on the strength of parent concrete from the obtained aggregate.

Limbachiya and Leelawat et al., (2000) found that Recycled concrete aggregate (RCA) had $7 \%$ to $9 \%$ lower relative density and 2 times higher water absorption than natural aggregate (NA). According to their test results, it shown that there was no effect with the replacement of $30 \%$ coarse recycled concrete aggregate (RCA) used on the ceiling strength of the concrete. It also mentioned that recycled concrete aggregate (RCA) might be used in high strength concrete mixes with the recycled concrete aggregate (RCA) content in the concrete.

Bodin and Zaharieva et al., (2000) stated that decreasing of the strength of recycled concrete specimen was due to the increase of $\mathrm{W} / \mathrm{C}$ ratio that required by the preservation of workability.

Nelson and Shing Chai NGO et al., (2004) the investigation was carried out using workability test, compressive test, indirect tensile test and modulus of elasticity test. There were total of 8 different batches of concrete mixtures, consists of each $20 \%$ addition of recycled aggregate substitute from $0 \%$ to $100 \%$. Moreover, $100 \%$ of recycled aggregate mix batches included fly ash, W/C ratio of 0.36 and 0.43 . The workability of concrete considerably reduced as the amount of recycled aggregate increased. This was evaluated through the standard slump test and compacting factor test. For strength characteristics, the results showed that a gradually decreasing in the compressive strength, tensile strength and modulus of elasticity as the percentage of recycled aggregate (RA) used in the specimens increased.
M C Limbachiya et al., (2004) showed that plain as well as reinforced concrete can be crushed using primary and secondary crushers to offer crushed aggregate with an acceptable quality to existing BS 882 requirements. Because of the attached cement paste in the RCAs, the density of these materials is about 3\%-10\% lower and water absorption is about 3 to 5 times higher than the corresponding natural aggregates. It is consequently important that density and water absorption of RCA are determined carefully, earlier to their use in concrete production. This must be done in order to avoid the large variations in properties of hardened concrete as well as in achieving the fresh concrete of adequate workability, stability and cohesiveness.

Winston F.K. Fong et al., (2004) discussed the latest application experience of using recycled aggregate in construction schemes in Hong Kong and recommend a broader scope of use of recycled aggregates in areas other than ready mixed concrete (RMC).

Michał Bołtryk and Dorota Małaszkiewicz et al., (2005) carried out test to determine the compressive strength. Concrete mixtures were produced at recycled aggregate content equal: $0 \%, 25 \%, 50 \%$ and $75 \%$ of coarse aggregate. Compressive strength of recycled aggregate concrete (RAC) explained a decrease of up to $6 \%$ compared to natural aggregate concrete (NAC). RAC water absorption was higher compared to NAC because of remains of mortar on its rough surface.

Ismail Abdul Rahman et al., (2009) described the effect of size of recycled aggregate on compressive strength. The $100 \%$ of RA used in concrete mix to replace the natural coarse aggregate (NCA) in concrete with $100 \mathrm{~mm} \times 100 \mathrm{~mm} \times 100 \mathrm{~mm}$ cube were cast with target compressive strength is $25 \mathrm{MPa}$. The 28-day compressive strength was crushed at 3, 14, 28 days are reported found that the size of $10 \mathrm{~mm}$ and 14 $\mathrm{mm}$ of RA in RAC is quite comparable performance with $10 \mathrm{~mm}$ and $14 \mathrm{~mm}$ size of natural aggregate (NA) in natural aggregate concrete (NAC).

Yong, P.C et al., (2009) found that the recycled aggregates that are obtained from site tested concrete specimen make good quality concrete. The compressive strength of recycled aggregate concrete (RAC) is found to be higher than the compressive strength of normal concrete. Recycled aggregate concrete (RAC) is in close proximity to normal 
concrete in terms of split tensile strength, flexural strength and wet density. The slump of recycled aggregate concrete is low and that can be improved by using saturated surface dry (SSD) coarse aggregate.

S. W. Tabsh and Abdelfatah (2009) deliberated the strength of concrete prepared with recycled coarse aggregate from used concrete. The toughness and soundness laboratory tests on the recycled coarse aggregate proved higher percentage loss than natural aggregate, but remained within acceptable limits. The compressive strength and splitting tensile strengths of concrete prepared with recycled coarse aggregate depend upon the mixture proportions. In common, the strength of recycled concrete was $10 \%-25 \%$ lower than that of conventional concrete made with natural aggregate due to increase in water demand to maintain the specified slump.

R. Kumutha et al., (2010) carried out tests to determine the density, split tensile strength, flexural strength, compressive strength and modulus of elasticity of concrete with and without recycled aggregates. Natural coarse aggregates (NCA) in concrete was replaced with $0 \%, 20 \%, 40 \%, 60 \%, 80 \%$ and $100 \%$ of crushed concrete aggregates. Naturally available fine aggregate in the concrete was replaced with $0 \%, 20 \%, 40 \%, 60 \%, 80 \%$ and $100 \%$ of crushed brick aggregates. For strength characteristics, the results showed a gradual decrease in compressive strength, split tensile strength, flexural strength and modulus of elasticity as the percentage of recycled aggregate used in the specimens increased.

Abdelfatah et al. (2010) utilized admixtures in the concrete mixture containing demolished concrete as replacement for natural coarse aggregates (NCA) to balance for the need of extra water required to increase the workability of the mixture. The test results showed that the use of super plasticizers, instead of additional water, was capable to increase the compressive strength of recycled aggregate concrete to a level around the same as that of the control mix containing natural aggregate. This finding is not in agreement with the results obtained by Gull (2011) when testing low strength concrete utilizing recycled concrete aggregate (RCA).

F. A. Mirza and M. A. Saif (2010) studied the effect of silica fume on recycled aggregate concrete characteristics. The percentages of recycled aggregate replacements of natural aggregate used by weight were $0 \%, 50 \%$, and $100 \%$, whereas the percentages of silica fume replacements of cement used by weight were $5 \%, 10 \%$ and $15 \%$. The results showed that tensile strengths and the compressive values of the recycled concrete aggregate (RCA) increased as the recycled aggregate and the silica fume contents increased. The study also shows that in order to accommodate $50 \%$ of recycled aggregate in the structural concrete, the mix needs to incorporate 5\% of silica fume.

Elchalakani (2010) investigated the strength and durability of recycled concrete made from recycled aggregate and waste water in the United Arab Emirates (UAE). Experimental tests employing standard cubes and cylinders to evaluate the compressive strength and small beams to evaluate the flexural strength were employed. The study also showed that the effect of recycled aggregate and recycled water on axial strength and bending strength was found reasonable but had a significant effect on durability. To enhance the durability of recycled concrete, the author suggested using ground granulated blast furnace slag and fly ash for any future building construction in the Gulf.

\section{2- Recycling of Construction and Demolition waste}

This segment discusses about the recycling process.

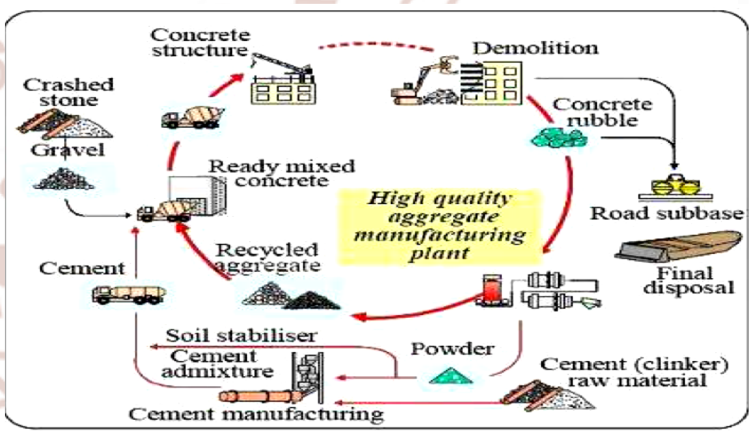

\section{Figure-1 Flow diagram of Concrete Recycling System}

\section{EXPERIMENTAL METHODOLOGY}

A variety of test specimens were prepared to determine the compressive strength, water absorption and other properties of the concrete mixture. The data is the reference of study experiment that has to be done. Experiments needed to be done to attain the objectives given are sieve analysis, specific gravity, water absorption, impact value and crushing strength of the aggregates. 


\section{1- Materials \& their Testing Methods}

a. Materials Used

Materials - Ordinary Portland Cement (OPC), fine aggregate and coarse aggregate.

\section{b. RCA-}

The main source of recycled concrete aggregate was demolished structure mainly the columns and beams which were free from any reinforcement or other contaminants, cubes from this material were casted and tested in the laboratory. The local crushing plants were not able to crush the concrete waste and thus the crushing and sieving had to be done manually. The concrete rubble remains were broken initially manually and then sieving was done using IS sieves. The process generated, recycled concrete aggregate$10 \mathrm{~mm}$ and recycled concrete aggregate $20 \mathrm{~mm}$ size.

\section{II) Testing Methods}

\section{a) Sieve Analysis Test}

Fineness modulus (F.M.) of aggregate is an index number which gives an idea about the coarseness or fineness of an aggregate.

Fineness modulus of an aggregate is approximate proportion of the average size of particles in the aggregate. Fineness modulus is determined by adding the cumulative percentage of material retained on each sieve and dividing the sum of cumulative percentage of material retained on each sieve by 100 . In this method, the fineness modulus of coarse and fine aggregate are determined separately. Prescribed values of F.M. is higher for coarse aggregate (i.e stone metals etc.) and is as follows

For $20 \mathrm{~mm}$ size $=6$ to 6.9

$40 \mathrm{~mm}$ size $=6.9$ to 7.5

For all in aggregate

$20 \mathrm{~mm}$ size $=4.8$ to 5.1

$25 \mathrm{~mm}$ size $=5.1$ to 5.5

\section{b) Specific Gravity Test}

Specific gravity is the ratio of the weight of given volume of dry aggregate to the weight of equal volume of distilled water.

\section{c) Water absorption Test}

Specific gravity is the ratio of the weight of given volume of dry aggregate to the weight of equal volume of distilled water.
Stones having higher water absorption values are porous and hence weak. They are generally unsuitable unless found acceptable based on crushing and grinding. The sample is weighted on water and the buoyant weight is found. The aggregate is taken out and weighted after the surface is dried. The specific gravity can be calculated by dividing dry weight of aggregate by weight of equal volume of water.

The water absorption is expressed as percentage water absorption in terms of oven dried weight of aggregate. The specific gravity of rock varies from 2.6 to 2.9. Rock specimen having more than 0.6 percent of water absorption is considered unsatisfactory.

\section{d) Impact Test}

The property of a material to resist impact is known as toughness. Due to movement of vehicles on the road the aggregates are subjected to impact resulting in their breaking down into smaller pieces. The aggregates should therefore have sufficient toughness to resist their disintegration due to impact. This characteristic is measured by impact value test. The aggregate impact value is a measure of resistance to sudden impact or shock, which differs from its resistance to gradually applied compressive load.

\section{e) Crushing value Test}

The strength of coarse aggregate may be determined by aggregate crushing strength test. The aggregate crushing value gives a relative measure of the resistance of an aggregate sample to crushing under gradually applied compressive load.

\section{f) Workability Test of Fresh Concrete}

According to Cement Manufacturer's Association India, a good concrete must have workability in the fresh state and also develop sufficient strength. It also mentioned that there are four factors that can affect the workability. They are as below:

$\checkmark$ Consistency: The degree of consistency is dependent on the nature of works and type of compaction.

Water/Cement Ratio or Water Control of a Concrete: Water/cement ratio is the ratio of water in a mix to the weight of cement. The quantity of water required for a mix depend on the mix proportions, types and grading of aggregate. 
International Journal of Trend in Scientific Research and Development (IJTSRD) ISSN: 2456-6470

$\checkmark$ Grading of Aggregate: The smooth and rounded aggregate will produce a more workable concrete than the sharp angular aggregate.

Cement Content: The greater workability can be obtained with the higher cement content.

\section{g) Compression Test}

According to Cement Association of India (2003), compressive strength of concrete can be defined as the measured maximum resistance of a concrete to axial loading. Compression test is the most common test used to test the hardened concrete specimens because the testing is easy to make. The strength of the concrete specimens with different percentage of recycled aggregate replacement can be indicated through the compression test.

The specimens used in the compression test were cubes of $150 \mathrm{~mm}$ X150 mm X $150 \mathrm{~mm}$ size. Six specimens were used in the compression testing for every batch of mix. Differences of the strength among the different percentage of recycled aggregate used at the age of 7 and 28 days was also indicated through the compression test. The compression testing procedures was according to the Indian Standard Code.

\section{EXPERIMENTAL INVESTIGATION}

\section{1- Mix Design and Casting of Concrete}

\section{Proportioning of concrete}

Prior to having any concrete mixing, the selection of materials and their proportion must be determined through the concrete mix design. There are various methods to determine concrete mix design. Five batches of mixtures were determined in this thesis.

The preliminary mix batch is using 100\% natural aggregate was used. In second mix batch $75 \%$ natural aggregate and $25 \%$ recycled aggregate. Successive batches were made by successively adding $25 \%$ extra recycled aggregates and corresponding decrease in natural aggregate as shown in Table-2.

First batch of mix called a control mixture used only natural aggregates, and four successive mixtures with increasing percentage of recycled aggregate and corresponding decrease of natural aggregate from $25 \%$ to $100 \%$ by weight. All these mixtures were prepared with cement and aggregate in the proportion by weight, and were expected to achieve a target compressive strength.
Table-2 Percentage of aggregate used in all 6 batches of mixes

\begin{tabular}{|l|l|l|l|l|l|l|}
\hline & $\begin{array}{l}\text { Batc } \\
\text { h 1 }\end{array}$ & $\begin{array}{l}\text { Batc } \\
\text { h 2 }\end{array}$ & $\begin{array}{l}\text { Batc } \\
\text { h 3 }\end{array}$ & $\begin{array}{l}\text { Batc } \\
\text { h 4 }\end{array}$ & $\begin{array}{l}\text { Batc } \\
\text { h 5 }\end{array}$ & $\begin{array}{l}\text { Batc } \\
\text { h 6 }\end{array}$ \\
\hline $\begin{array}{l}\text { Natural } \\
\begin{array}{l}\text { Aggrega } \\
\text { te (\%) }\end{array}\end{array}$ & 100 & 80 & 60 & 40 & 20 & 0 \\
\hline $\begin{array}{l}\text { Recycle } \\
\text { d } \\
\begin{array}{l}\text { Aggrega } \\
\text { te }(\%)\end{array}\end{array}$ & 0 & 20 & 40 & 60 & 80 & 100 \\
\hline
\end{tabular}

\section{2- Water Absorption}

Water absorption is the amount of moisture content absorbed by the aggregate. The water absorption capacity is based on the saturated surface dry condition and oven dried condition. The amount of water in a concrete mixture has direct effect on the setting time and compressive strength of the concrete. Moisture content of the aggregate has to determine first before preparing a mix for a particular aggregate. Before making mix either the aggregates has to be moistened to surface dry condition or surplus/extra water as per the percentage, has to be added to the mix.

The water absorption capacity of recycled aggregate is higher than natural aggregate .The average water absorption of recycled aggregate is around 5.0\%, but water absorption of natural aggregate is only $2.20 \%$.This shows that water absorption of recycled aggregate is around 2.5 times of natural aggregate. This result shows that more water needed to be added when using recycled aggregate in the concrete mixing to get an acceptable workability.

\section{Table-3 Water Absorption Test Results}

\begin{tabular}{|c|c|c|c|}
\hline S. No & Details & RCA & NA \\
\hline 1 & $\begin{array}{l}\text { Wt. of empty } \\
\text { Container }=\mathrm{W} 1\end{array}$ & 2.0 & 2.0 \\
\hline 2 & $\begin{array}{l}\text { Wt. of } \begin{array}{r}\text { soaked } \\
\text { aggregates }+ \text { Container } \\
=\mathrm{W} 2\end{array} \\
\end{array}$ & 3.4 & 4.5 \\
\hline 3 & $\begin{array}{l}\text { Wt. of oven dried } \\
\text { aggregates }+ \text { Wt. of } \\
\text { container }=\mathrm{W} 3\end{array}$ & 1.93 & 1.945 \\
\hline 4 & $\begin{array}{l}\% \text { Water absorption }= \\
(\mathrm{W} 1-\mathrm{W} 3 / \mathrm{W} 2-\mathrm{W} 1)^{*} 100\end{array}$ & $5 \%$ & $2.20 \%$ \\
\hline
\end{tabular}


International Journal of Trend in Scientific Research and Development (IJTSRD) ISSN: 2456-6470

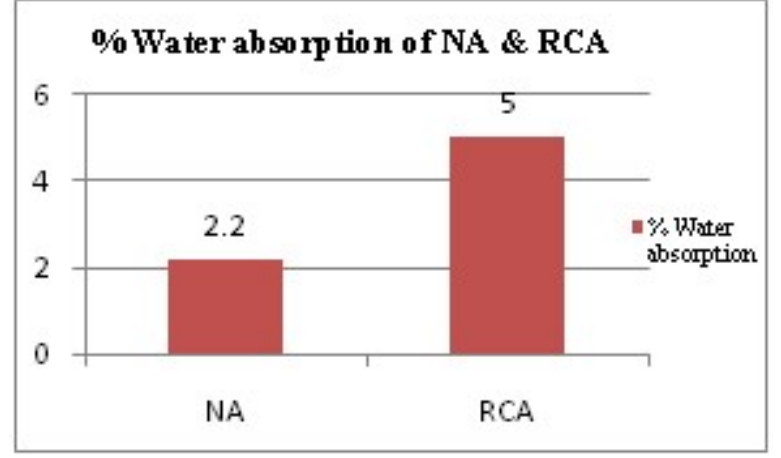

Graph-1 Water Absorption of Aggregates

\section{3- Specific Gravity}

The specific gravity of natural aggregate is around 2.75 and recycled aggregate is having 2.85 this means that the recycled aggregate is stronger than the natural aggregate in this case. Fine aggregate is having the specific gravity value of 2.65 .

Table-4 Specific Gravity test

\begin{tabular}{|c|c|c|c|c|}
\hline $\begin{array}{l}\text { S. } \\
\text { No }\end{array}$ & Details & RCA & $\mathbf{N A}$ & Sand \\
\hline 1) & $\begin{array}{l}\text { Wt. of empty } \\
\text { Pycnometer =W1 }\end{array}$ & $\begin{array}{l}0.644 \\
\mathrm{~kg}\end{array}$ & $\begin{array}{l}0.644 \\
\mathrm{~kg}\end{array}$ & $0.644 \mathrm{k}$ \\
\hline 2) & $\begin{array}{l}\text { Wt. } \\
\text { Pycnometer } \\
\text { Aggregates/Sand } \\
=W 2\end{array}$ & $\begin{array}{l}0.844 \\
\mathrm{~kg}\end{array}$ & $\begin{array}{l}0.848 \\
\mathrm{~kg}\end{array}$ & $\begin{array}{l}0.848 \mathrm{~kg} \\
\text { Rese }\end{array}$ \\
\hline 3) & $\begin{array}{l}\text { Wt. } \\
\text { Pycnometer } \\
\text { Aggregates } \\
\text { Water =W3 }\end{array}$ & $\begin{array}{l}1.632 \\
\mathrm{~kg}\end{array}$ & $\begin{array}{l}1.632 \\
\mathrm{~kg}\end{array}$ & $\begin{array}{l}1.629 \mathrm{~kg} \\
6 \mathrm{SN}\end{array}$ \\
\hline 4) & $\begin{array}{lc}\text { Wt. } & \text { of } \\
\text { Pycnometer } & + \\
\text { Water = W4 } & \end{array}$ & $\begin{array}{l}1.502 \\
\mathrm{~kg}\end{array}$ & $\begin{array}{l}1.502 \\
\mathrm{~kg}\end{array}$ & $1.502 \mathrm{~kg}$ \\
\hline 5) & $\begin{array}{l}\text { Specific } \\
\text { Gravity=(W2- } \\
\text { W1)/(W2-W1)- } \\
\text { (W3-W4) }\end{array}$ & 2.85 & 2.75 & 2.65 \\
\hline
\end{tabular}

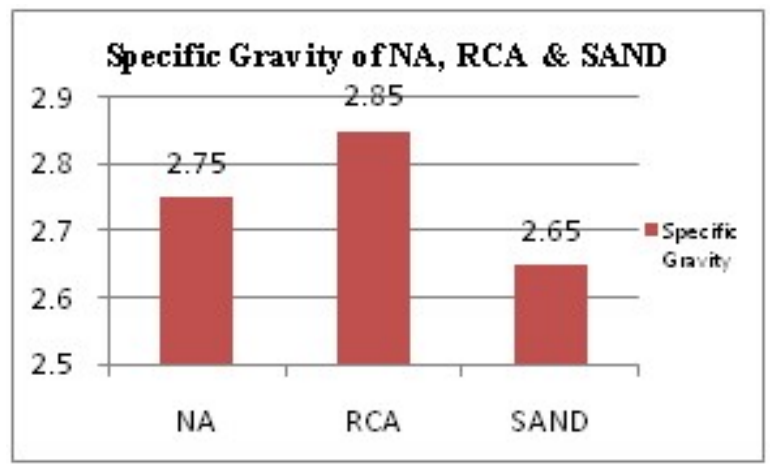

Graph-2 Specific Gravity of Aggregate 4- Aggregate Crushing Value and Impact Value

From the test result of crushing value we come up to know that the recycled aggregate is having less resistance to the wear and tear than the natural aggregate (NA). Impact test is the excellent indicator of strength and durability from the test result we can say that natural aggregate (NA) and recycled aggregate (RA) are having very less difference in impact value and crushing value, which again shows that rock of recycled aggregate can also used as natural aggregate.

\section{Table-5 Crushing Value Test}

\begin{tabular}{|l|l|l|l|}
\hline Sample & $\begin{array}{l}\text { Total } \\
\text { Wt. of } \\
\text { dry } \\
\text { sample } \\
\text { (W1) }\end{array}$ & $\begin{array}{l}\text { Weight } \\
\text { of fine } \\
\text { passing } \\
2.36 \mathrm{~mm} \\
\text { IS sieve } \\
\text { (W2) }\end{array}$ & $\begin{array}{l}\text { Aggregate } \\
\text { crushing Value } \\
= \\
\text { (W2/W1)*100 }\end{array}$ \\
\hline $\begin{array}{l}\text { Recycled } \\
\begin{array}{l}\text { Concrete } \\
\text { Aggregate } \\
\text { (RCA) }\end{array}\end{array}$ & $4 \mathrm{~kg}$ & $0.95 \mathrm{~kg}$ & $23.75 \%$ \\
\hline $\begin{array}{l}\text { Natural } \\
\text { Aggregate } \\
\text { (NA) }\end{array}$ & $4 \mathrm{~kg}$ & $0.805 \mathrm{~kg}$ & $20.13 \%$ \\
\hline
\end{tabular}

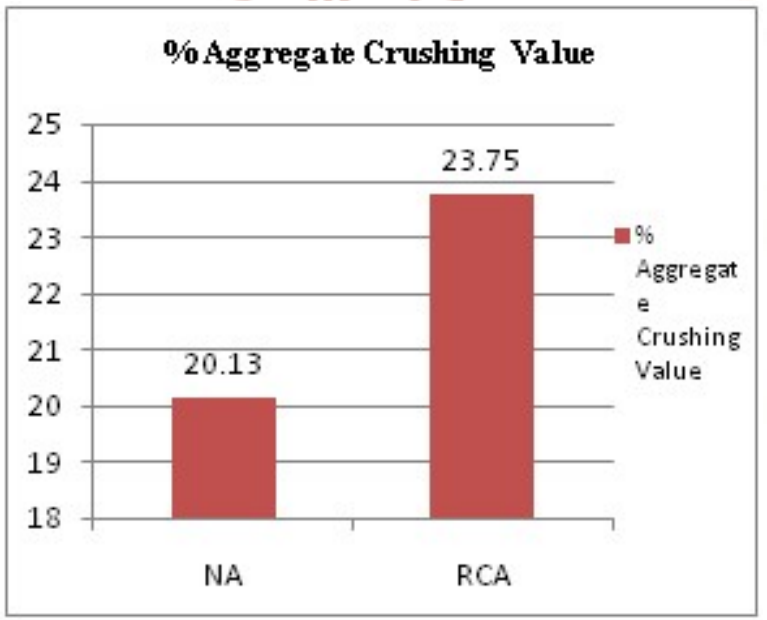

Graph-3 Crushing Value of Recycled concrete aggregate (RCA) and Natural Aggregate (NA) 
International Journal of Trend in Scientific Research and Development (IJTSRD) ISSN: 2456-6470

Table-6 Aggregate Impact Value test

\begin{tabular}{|c|c|c|c|c|c|c|c|}
\hline \multirow{2}{*}{$\begin{array}{l}\text { S. } \\
\text { No }\end{array}$} & \multirow[t]{2}{*}{ Details } & \multicolumn{3}{|l|}{$\mathbf{R A}$} & \multicolumn{3}{|l|}{ NA } \\
\hline & & $\begin{array}{l}\text { Trial1 } \\
\text { (kg) }\end{array}$ & $\begin{array}{l}\text { Trail2 } \\
\text { (kg) }\end{array}$ & $\begin{array}{l}\text { Avg. } \\
\text { (kg) }\end{array}$ & $\begin{array}{l}\text { Trial1 } \\
(\mathrm{kg})\end{array}$ & $\begin{array}{l}\text { Trail2 } \\
(\mathrm{kg})\end{array}$ & $\begin{array}{l}\text { Avg. } \\
(\mathbf{k g})\end{array}$ \\
\hline 1) & $\begin{array}{l}\text { Total wt. of aggregates sample filling } \\
\text { the cylindrical measure }=\mathrm{W} 1\end{array}$ & 0.546 & 0.576 & $11.89 \%$ & 0.625 & 0.630 & $7.81 \%$ \\
\hline 2) & $\begin{array}{l}\text { Wt. of aggregates passing } 2.36 \mathrm{~mm} \\
\text { sieve after the test }=\mathrm{W} 2\end{array}$ & 0.068 & 0.060 & & 0.056 & 0.040 & \\
\hline 3) & $\begin{array}{l}\text { Wt. of aggregates retained on } 2.36 \mathrm{~mm} \\
\text { sieve after the test }=\mathrm{W} 3\end{array}$ & 0.478 & 0.516 & & 0.569 & 0.590 & \\
\hline 4) & $\begin{array}{lll}\begin{array}{l}\text { Aggregate } \\
(\mathrm{W} 2 / \mathrm{W} 1)^{*} 100\end{array} & \text { impact } & \text { value }=\end{array}$ & $12.45 \%$ & $10.41 \%$ & & $8.96 \%$ & $6.66 \%$ & \\
\hline
\end{tabular}

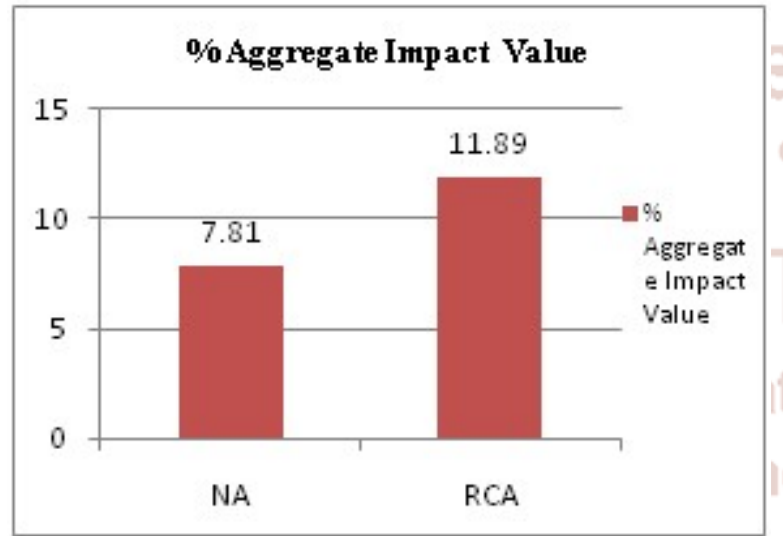

Graph-4 Impact Value of Recycled Aggregate and Natural Aggregate

\section{TEST RESULTS AND ANALYSIS}

Chains of tests were carried out on the materials, fresh and hardened concrete to obtain the strength characteristics of recycled aggregate (RA) for potential application as a structural concrete. The results for material test like water absorption, specific gravity, aggregate crushing value and aggregate impact value (AIV) test are given in Table-7 below. Compressive strength of hardened concrete is reported in Table-8.

Table-7 Final result of all tests on Materials

\begin{tabular}{|l|l|l|l|l|}
\hline $\begin{array}{l}\text { S. } \\
\text { No }\end{array}$ & Particulars & $\begin{array}{l}\text { Natural } \\
\text { Aggregate }\end{array}$ & $\begin{array}{l}\text { Recycled } \\
\text { Aggregate }\end{array}$ & Sand \\
\hline 1 & $\begin{array}{l}\text { Water } \\
\text { Absorption }\end{array}$ & $1.83 \%$ & $5.00 \%$ & - \\
\hline 2 & $\begin{array}{l}\text { Specific } \\
\text { gravity }\end{array}$ & 2.75 & 2.85 & 2.65 \\
\hline 3 & $\begin{array}{l}\text { Agg.Crushin } \\
\text { g Value }\end{array}$ & $20.02 \%$ & $22.50 \%$ & - \\
\hline 4 & $\begin{array}{l}\text { Agg. Impact } \\
\text { Value }\end{array}$ & $7.81 \%$ & $11.89 \%$ & - \\
\hline
\end{tabular}

\section{Compressive Strength Test Result}

The compressive strength test by CTM (Compression Testing machine) shows an increasing trend of the compressive strength with age of the concrete specimens. However, it shows that the compressive strength of the recycled aggregate (RA) specimens is lower than the natural aggregate (NA) specimens. Table- 8 below shows the increase of the compressive strength with age recorded during the test. Graphs-5 below shows the variation in the compressive strength which exhibiting decreasing trend in successive batches, which containing higher replacement levels.

Table-8 Variation of compressive strength $\left(\mathrm{kg} / \mathrm{cm}^{2}\right)$ with age

\begin{tabular}{|l|l|l|l|l|l|}
\hline $\begin{array}{l}\% \text { of } \\
\text { RAC }\end{array}$ & $0 \%$ & $25 \%$ & $50 \%$ & $\mathbf{7 5} \%$ & $\mathbf{1 0 0 \%}$ \\
\hline 7 & 164 & 147 & 138 & 124 & 112 \\
DAYS & $\mathrm{kg} / \mathrm{cm}^{2}$ & $\mathrm{~kg} / \mathrm{cm}^{2}$ & $\mathrm{~kg} / \mathrm{cm}^{2}$ & $\mathrm{~kg} / \mathrm{cm}^{2}$ & $\mathrm{~kg} / \mathrm{cm}^{2}$ \\
\hline 28 & 250 & 238 & 228 & 208 & 198 \\
DAYS & $\mathrm{kg} / \mathrm{cm}^{2}$ & $\mathrm{~kg} / \mathrm{cm}^{2}$ & $\mathrm{~kg} / \mathrm{cm}^{2}$ & $\mathrm{~kg} / \mathrm{cm}^{2}$ & $\mathrm{~kg} / \mathrm{cm}^{2}$ \\
\hline
\end{tabular}

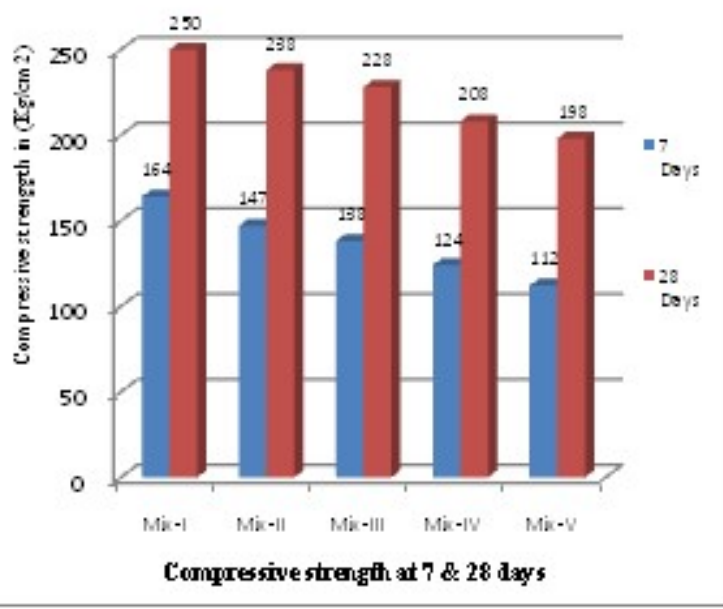

Graph-5 Variation in Compressive Strength with Age and increasing \% of RA 
The target mean strength for our thesis work was 250 $\mathrm{kg} / \mathrm{cm}^{2}$ obtained results shows that the mixes that met the target strength were having $0 \%, 25 \%, 50 \%, 75 \%$ and $100 \%$ content of recycled aggregate. The compressive strength for other mixes is around 250 $\mathrm{kg} / \mathrm{cm}^{2}$. At the same time as using the recycled aggregate the compressive strength of the concrete a specimen for $100 \%$ recycled aggregate with 0.55 water/cement ratio is $198 \mathrm{~kg} / \mathrm{cm}^{2}$.

The test result also shows that the concrete specimens with higher percentage of the replacement of recycled aggregate provide the lowest compressive strength as compared to the concrete specimens with lesser percentage of recycled aggregate. prepared with used or recycled aggregate can be checked.

2) Partial replacement of cement by other pozzolanic material in the mix can also be tested.

3) The effect of admixtures like water reducer, accelerator, superplasticizer and retarder on the various properties of the mix can also be examined.

4) The effect of fly ash, silica fume and their combination can also be checked for various properties of the prepared concrete mixture.

5) The various prepared mixes of concrete can be checked for different other properties like split tensile strength, flexural strength and other long term properties can also be determined.

\section{CONCLUSIONS RECOMMENDATIONS}

\section{1- Conclusion}

These are the following conclusions after performing the various tests on different mixes prepared with varying percentage of recycled aggregate.

1. By the compressive strength test results we come to know that as the percentage of Natural Aggregate decreases in the mix, the corresponding strength of the mix also slightly decreases.

2. The workability of the mix prepared with variable percentage of recycled aggregate also gives the satisfactory slump.

3. At the time of selection of water cement ratio when using recycled aggregate in the mix special care should be taken because recycled aggregate are more porous than natural aggregate.

4. The $50 \%$ natural aggregate can be replaced by recycled aggregate without much more compromising with the compressive strength of the concrete.

5. By using recycled aggregate in the new concrete mix we can save the money as well as environment because stone crushing creates sound and air pollution.

\section{2- Recommendations for Future Work}

These are the some recommendation for future work like various study aspects and testing in the field of recycled aggregate concrete.

1) The effect of addition of fibrous materials in the concrete mix on the various properties of concrete

\section{REFERENCES}

1. A. Abdelfatah, S. W. Tabsh, and S. Yehia, "Alternative ways of making concrete with recycled coarse aggregate," in Proceedings of the 4th International Conference on Applications of Traditional and High Performance Materials in Harsh Environments, Institute of Materials Systems, Sharjah, UAE, March 2010.

2. Building Innovation and Construction Technology, 1999, Recycled Hit, New High, viewed 30 August 2004.

3. Buyle - Bodin, F. and Hadijieva-Zaharieva, R. (2000), "Influence of Industrial Produced Recycled Aggregate on Flow Properties of Concrete," Material and Structures, Vol. 35, pp. 504-509.

4. CRISO and Wilmot, Commonwealth Scientific and Industrial Research Organisation, viewed 4 April 2004.

5. F. A. Mirza and M. A. Saif, "Mechanical properties of recycled aggregate concrete incorporating silica fume," in Proceedings of the 2nd International Conference on Sustainable Construction Materials and Technologies, Coventry University and The University of Wisconsin Milwaukee Centre for By-products Utilization, Ancona, Italy, June 2010.

6. Fact File C \& D Recycling Industry, n.d., History, viewed 11 April 2004.

7. Fong F. K. Winston, Yeung S. K. Jaime, and Poon, C. S., "Hong Kong Experience of Using Recycled Aggregate from Construction and Demolished Materials in Ready Mix Concrete," viewed 26 Jun 2004. 
8. Hong Kong Housing Department, Use of Recycled Aggregate, viewed 25 March 2004.

9. I. Gull, "Testing of strength of recycled waste concrete and its applicability," Journal of Construction Engineering and Management, vol. 137, no. 1, pp. 1-5, 2011.

10. Ismail Abdul Rahman and Hasrudin Hamdam (2009), "Assessment of Recycled Aggregate Concrete," Modern Applied Science, vol.3, No.10, pp. 47-54.

11. Kajima Corporation Research and Development, 2002, Recycled Aggregate Concrete for WithinSite Recycling, viewed 9 September 2004.

12. Kumutha, R. and Vijai, K. (2010), "Strength of Concrete Incorporating Aggregates Recycled from Demolished Waste," ARPN Journal of Engineering and Applied Sciences, vol.5, No.5, pp. 64-71.

13. Limbachiya, M. C., Leelawat, T. and Dhir, R. K. (2000), "Use of Recycled Concrete Aggregate in High-Strength Concrete," Material and Structure, Vol. 33, pp. 574-580.

14. Limbachiya, M. C., Koulouris, A., Roberts, J. J. and Fried, A. N. (2004), "Performance of Recycled Aggregate Concrete," RILEM Publications SARL, pp. 127-136.

15. M. Elchalakani, "Strength and durability of recycled concrete made from recycled aggregate and wastewater," in Proceedings of the International Concrete Sustainability Conference, The National Ready Mixed Concrete Association and Grey Matters Consultancy, Dubai, UAE, December 2010.

16. Mac Naughton, I. (2004). “Ontario's Aggregates Are a Diminishing Resource," Ontario Hot Mix Producers Association Fall Seminar Presentations, December 8.

17. Mehta, P.K., and Monteiro, P.J.M. (2005). "Concrete: Microstructure, Properties, and Materials," $3^{\text {rd }}$ Edition, McGraw-Hill Companies Inc., New York, NY.

18. Mehus and Lillestol, 2000, Norwegian Building Research Institute, viewed 3 March 2004.

19. Michał Bołtryk, Dorota Małaszkiewicz and Edyta Pawluczuk, "Basic Technical Properties of Recycled Aggregate Concrete," viewed 2005.

20. Miller, G. (2005). "Running Out of Gravel and Rock," Toronto Star, January 6, p. A22.

21. Naik, T.R., and Moriconi, G. (2005). "Environmental-Friendly Durable Concrete Made with Recycled Materials for Sustainable Concrete Construction," International Symposium on
Sustainable Development of Cement, Concrete and Concrete Structures, Toronto, Ontario, October 5-7, pp. 277-298.

22. Nelson and Shing Chai NGO, "High-Strength Structural Concrete with Recycled Aggregate," viewed 2004.

23. Oikonomou, N. D. (2005),"Recycled concrete aggregate (RCA)," Cement \& Concrete Composites, Vol. 27, pp. 315-318.

24. Ramammurthy, K. \& Gumaste, K.S. (1998), "Properties of Recycled Aggregate Concrete," Indian Concrete Journal, pp. 49-53.

25. Roos F., 1998, Verification of the Dimensioning Values for Concrete with Recycled concrete aggregate (RCA), viewed 27 February 2004.

26. S. W. Tabsh and A. S. Abdelfatah, "Influence of Recycled concrete aggregate (RCA) on strength properties of concrete," Construction and Building Materials, vol. 23, no. 2, pp. 1163-1167,2009.

27. Sagoe and Brown (1998) Reuse of recycled aggregates and other $\mathrm{C} \& \mathrm{D}$ wastes.

28. Tavakoli, M. and Soroushian, P. (1996), "Strength of Recycled Aggregate Concrete made using Field Demolished Concrete as Aggregate," ACI Materials Journal, Vol. 93, No.2, pp. 182-190.

29. Vyncke, J. Demyster, E. (1994), "Recycling and Construction and Demolition Waste in Belgium : Actual Situation and Future Evaluation," Demolition and Reuse of Concrete \& Masonry, Rilem Proceeding 23, E\&FN Spon, pp. 57- 69.

30. Water Pollution and Land Contamination, n.d., Controlling Environmental Effect, Recycled and Secondary Aggregate Production, viewed 5 May 2004.

31. Yong, P. C. and Teo, D. C. (2009), "Utilisation of Recycled Aggregate as Coarse Aggregate in Concrete," UNIMAS E-Journal of Civil Engineering, vol. 1, issue1, pp 1-6. 